Ananiy Kohut', Roman. Fleychuk ${ }^{2}$, Orest $\mathrm{Hevus}^{2}$ and Stanislav Voronov ${ }^{2}$

\title{
MACROINITIATORS ON THE BASIS OF NEW PEROXIDE SURFACE ACTIVE MONOMERS
}

\author{
${ }^{1}$ Institute of Particle Technology, University of Erlangen-Nuremberg, Erlangen, Germany \\ ${ }^{2}$ Lviv Polytechnic National University, 12 Bandera Str., Lviv, 79013, Ukraine \\ fleychuk@polynet.Iviv.ua
}

Received: March 27, 2007

\begin{abstract}
The surface active properties of new peroxide maleic monomers were investigated. The regularities of their copolymerization with styrene were studied. Peroxide polymers containing ditertiary alkyl peroxide groups in side substituents of backbone as the prospective hightemperature free radical macroinitiators were synthesized.
\end{abstract}

Keywords: copolymerization, macromonomers, monomers, peroxides, surfactants.

\section{Introduction}

The use of peroxide monomers in the reactions of copolymerization permits the introduction of peroxide groups into the macromolecule structure [1], which are able to generate free radicals including macroradicals. That is why, such polymers are able to initiate various radical processes, e.g. graft polymerization, vulcanization, structurizing. The utilization of peroxide macroinitiators enables to synthesize polymers with complex molecular architectures [2].The modification of diverse micro- and macrosurfaces with peroxide macroinitiators allows to design polymer nanolayers on these surfaces by the initiation of radical polymerization of vinyl monomers from them [2]. Specifically, it permits to obtain core-shell latex particles as well as perform pigment surface modification with the purpose of improving the dispersibility of pigment particles. On the other hand, the formation of polymer colloid systems by the reactions of copolymerization using surface active monomers (surfmers) is known to be one of the most convenient ways for their stabilization due to the covalent tethering of surfactant onto latex particle surface $[3,4]$. These systems are stable with regard to electrolytes as well as over wide $\mathrm{pH}$ and temperature ranges. Polymer films with improved physical-chemical and exploitational properties are formed on the basis of the latexes obtained with surfmer utilization. A surfmer molecule consists at least of three different parts: polymerizable group, as a rule, a carbon-carbon double bond, and of hydrophilic and oleophilic parts as a conventional surfactant. The hydrophilic groups may be both ionic (anionic or cationic) and non-ionic (e.g., an oxyethylene chain of an appropriate chain length). Hydrocarbon chains (alkyl chains, alkyl phenol chains) or polypropylene oxide and polybutylene oxide chains are used as hydrophobic molecule parts. Maleic surfmers are known to have an additional advantage over other surface active monomers. They do not undergo homopolymerization [5] and this means that the surfmers do not produce water soluble polymers (polysoaps) in the aqueous phase [6]. However, they copolymerize with other monomers. Maleic surfmer is covalently anchored onto the surface of the polymer particles at the emulsion or dispersion polymerization process and therefore it is not practically incorporated into the polymer bulk.

This work is devoted to the study of surface active properties and polymerization ability of non-ionic and anionic peroxide monomers of the following structures:<smiles>CC(C)(C)OC(C)(C)CCOC(=O)/C=C\C(=O)O</smiles><smiles>CC[NH2+]C(C)(C)OC(C)(C)CCOC(=O)/C=C\C(=O)OCCC[Sb](=O)(=O)OC</smiles><smiles>[2H][14CH]([2H])OCCOC(=O)/C=C\C(=O)OCCC(C)(C)OC(C)(C)C</smiles>

This kind of polymerizable surfactants seemed to be prospective for utilization in adhesives, coating formations etc. 


\section{Experimental}

\subsection{M aterials}

The monomers 1-3 were prepared by the methods reported in previous papers listed below. In short, 3-tertbutylperoxy-3-methylbutyl maleate 1 was synthesized by acylation of 3-tert-butylperoxy-3-methyl-1-butanol with maleic anhydride [7]. The anionic monomer 2 was synthesized by the interaction of triethylammonium salt of monomaleate 1 with 1,3-propane sultone in dimethyl formamide [8]. The acylation of poly(ethylene glycol) with molecular weight $300 \mathrm{~g} / \mathrm{mol}$ by the chloroanhydride of hemiester $\mathbf{1}$ gives the non-ionic surface active peroxide macromonomer 3 [8].

Styrene from Aldrich was distilled under reduced pressure just before utilization. The initiator, 2,2'azobis(isobutyronitrile), AIBN, from Merck was purified by recrystalization three times from anhydrous methanol. Methanol from Aldrich was dried by boiling with magnesium chips under reflux for 2-3 h and distilled. Triethylamine from Merck was used as supplied. All experiments were performed with deionized water.

\subsection{Copolymerization in solution}

Copolymerization of peroxide surfmer 3 with styrene was carried out at $333 \mathrm{~K}$ in benzene solution. The volume ratio solvent : monomer mixture was of $5: 1$, initiator - AIBN ( $2 \% \mathrm{w} / \mathrm{w}$ upon the monomer mixture). The polymerization proceeded till monomer conversion of $12-16 \%$. The copolymerization was performed in ampoules where benzene solution of maleate $\mathbf{3}$, styrene, and AIBN had been charged. The ampoule contents were cooled to $195 \mathrm{~K}$, whereupon, vacuumized and charged with argon five times in turn repeatedly. Then, ampoules were sealed. The polymers formed were purified by three precipitation cycles from benzene to hexane. The polymers were finally dried in vacuum at room temperature up to constant weight and copolymer yields were calculated. Copolymer composition was determined from elemental analysis data and/or hydroxyl group content determined as shown below.

\subsection{M easurements}

The surface active characterization of maleic surfmers 1-3 was carried out by means of surface tension measurements. These measurements were performed with a du Noby ring tensiometer at $293 \mathrm{~K}$. A weighed portion of the peroxide surfmer $\mathbf{1}$ was dissolved in water containing equimolar amount of triethylamine to measure the surface tension.

Hydroxyl number of the copolymers prepared was determined by the method of acetylation with acetic anhydride catalyzed by perchloric acid in pyridine [9].

\section{Results and Discussion}

Surface tension of aqueous solution of the peroxide surfmers 1-3 with the concentration, C \% w/w, at 293K, are represented as semilogarithmic plots in Figure 1.

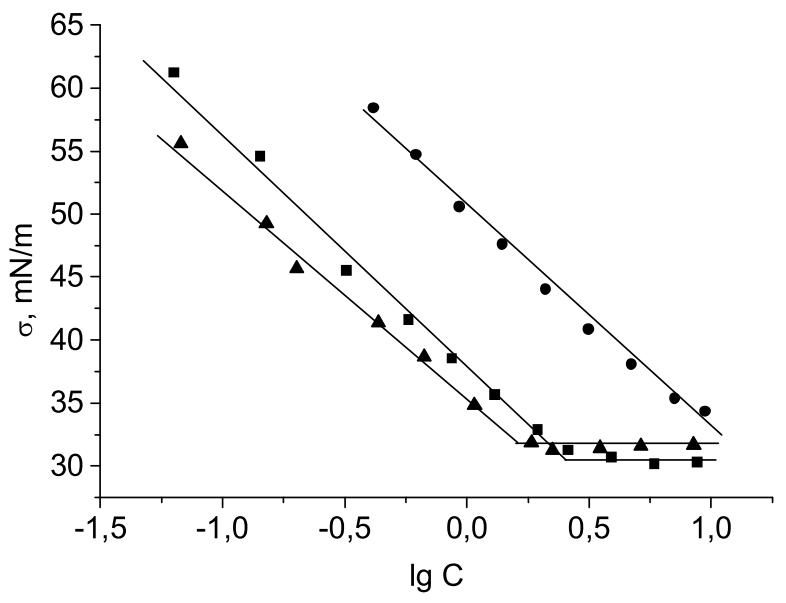

Fig. 1. Semilogarithmic plots of surface tension $s$ of peroxide monomer solution vs. monomer concentration, $\mathrm{C} \% \mathrm{w} / \mathrm{w}$, at $293 \mathrm{~K}:(\bullet)$ triethylammonium salt of surfmer 1;

(ם) surfmer 2; (A) surfmer 3

All the investigated peroxide monomers are obviously the surface active substances, since water surface tension decreases when the surfactants are added. The monomers $\mathbf{2}$ and $\mathbf{3}$ are colloidal surfactants. The surface tension decreases almost linearly with increasing concentrations of each of the surfmers and becomes constant above certain concentrations that evidently corresponds to their critical micelle concentrations $(\mathrm{cmc})$. The monomer 1 forms true aqueous solutions up to the saturation. Above this concentration, it forms a separate phase.

The cmc values determined from an inflection point and the surface tensions at these values have been listed in Table 1.

\section{Critical micelle concentration $(\mathrm{cmc})$ and the surface tensions at the $\mathrm{cmc}$ of the peroxide monomers}

Table 1

\begin{tabular}{|c|c|c|c|}
\hline \multirow{2}{*}{ monomer } & \multicolumn{2}{|c|}{$\mathrm{cmc}$} & $\sigma_{\mathrm{cmc}}$ \\
\cline { 2 - 4 } & $\% \mathrm{w} / \mathrm{w}$ & $\mathrm{mol} / 1$ & $\mathrm{mN} / \mathrm{m}$ \\
\hline $\mathbf{2}$ & 2.49 & 0.050 & 30.5 \\
\hline $\mathbf{3}$ & 1.61 & 0.029 & 31.7 \\
\hline
\end{tabular}

The synthesized surfmers are able to copolymerize with other monomers to form polymers with peroxide groups in side substituents of macrochain: 
The copolymerization of maleic macromonomer 3 $\left(M_{2}\right)$ on the basis of PEG-300 with styrene $\left(M_{1}\right)$ has been studied to determine the copolymerization constants. The results of the studies are presented in Table 2.

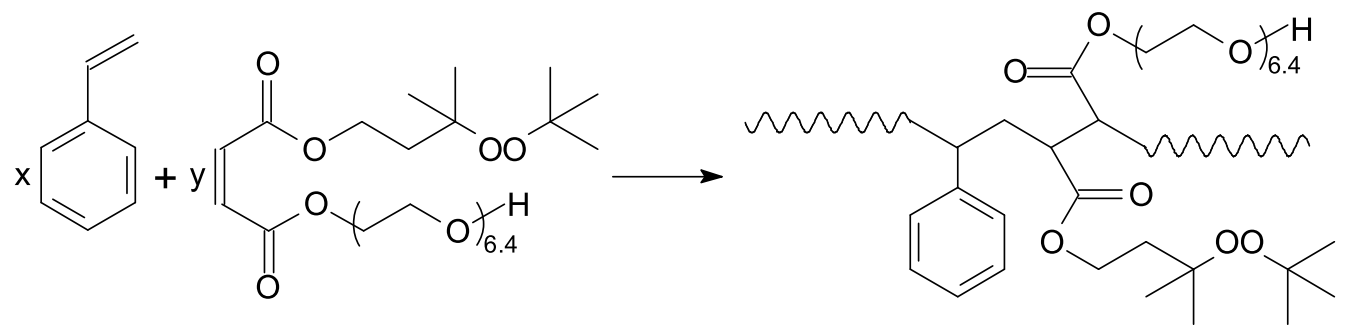

Table 2

Results of styrene $\left(M_{1}\right)$ copolymerization with the peroxide monomer $3\left(M_{2}\right)$

\begin{tabular}{|c|c|c|c|c|c|}
\hline \multirow{2}{*}{$\begin{array}{c}\text { Monomer mixture } \\
\text { composition, } \\
{\left[\mathrm{M}_{1}\right]:\left[\mathrm{M}_{2}\right]}\end{array}$} & \multicolumn{2}{|c|}{$\begin{array}{c}\text { Elemental composition of copolymers, \% } \\
\mathrm{w} / \mathrm{w}\end{array}$} & $\begin{array}{c}\text { Hydroxyl } \\
\text { number of } \\
\text { copolymers, } \\
\mathrm{mg} \mathrm{KOH} / \mathrm{g}\end{array}$ & $\begin{array}{c}\text { Copolymer } \\
\text { composition, } \\
{\left[\mathrm{m}_{1}\right]:\left[\mathrm{m}_{2}\right]}\end{array}$ \\
\cline { 2 - 5 } & $\mathrm{C}$ & $\mathrm{H}$ & $\mathrm{O}$ & 4.2 & $0.9921: 0.0079^{\mathrm{a})}$ \\
$0.9517: 0.0483$ & 90.77 & 7.77 & $? 1.5$ & 8.9 & $0.9825: 0.0175^{\mathrm{a})}$ \\
$0.8970: 0.1030$ & 89.08 & 7.82 & $? 3$ & 22.0 & $0.9518: 0.0482^{\mathrm{b})}$ \\
$0.6518: 0.3482$ & 84.48 & 7.93 & 7.59 & 30.3 & $0.9272: 0.0728^{\mathrm{b})}$ \\
$0.5012: 0.4988$ & 71.46 & 8.00 & 10.54 & 42.7 & $0.8827: 0.1173^{\mathrm{b})}$ \\
\hline
\end{tabular}

a) determined from hydroxy group content.

b) determined from elemental analysis data and hydroxy group content

The polymerization constants calculated according to the Mayo-Lewis method using the composition equation in the integrated form [10] are: $r_{1}=6.3 \pm 0.2 ; r_{2} \rightarrow 0$. Figure 2 represents the composition diagram of the copolymer.

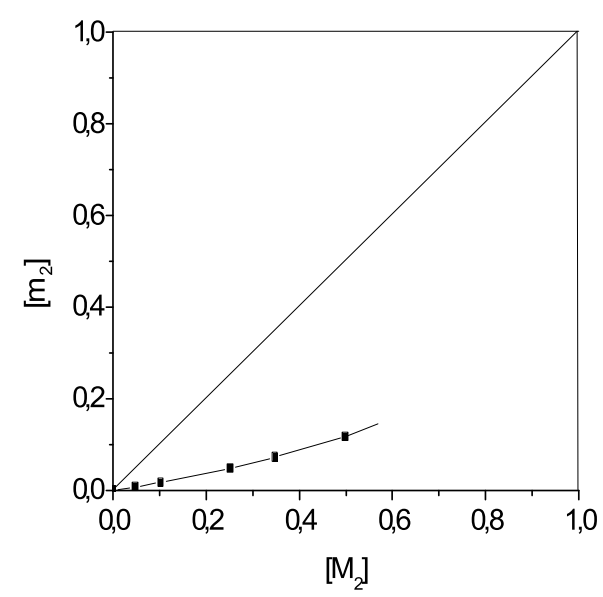

Fig. 2. The composition curve of the copolymer of styrene $\left(M_{1}\right)$ with the surface active peroxide macromonomer $3\left(\mathrm{M}_{2}\right)$
One can see from Figure 2 that copolymers enriched with styrene links in comparison with monomer mixture compositions are formed during copolymerization of macromonomer 3 with styrene in benzene solution.

\section{Conclusions}

The investigated peroxide maleic monomers are shown to possess surface active properties decreasing surface tension at the air/water interface. The critical micelle concentrations and the surface tensions at the $\mathrm{cmc}$ have been determined for corresponding peroxide monomers. The peroxide surfmers were shown to be able to copolymerize with traditional monomers retaining their peroxide group. As a result, prepared copolymers contain -O:O- groups in side substituents of skeleton macrochain that are able to initiate free radical processes: graft copolymerization; vulcanization; structurizing etc. The regularities of copolymerization of surface active monomers with styrene have been studied and the copolymerization constants were determined. The addition of poly(ethylene glycol) based maleic macromonomer to its own radical link is impossible during the 
copolymerization with styrene because of steric factors. That is why styrene only is added to the maleate radical as it is indicated by the copolymerization $r_{2}$ value. The monomers studied possess the surface active properties and may be utilized as polymerizable emulsifiers to perform the processes of emulsion polymerization of conventional vinyl monomers (styrene, acrylates, methacrylates etc.).

\section{References}

[1] Voronov S., Tokarev V., Oduola K., et.al.: J. Appl. Polym. Sci., 2000, 76, 1217.

[2] Voronov S., Tokarev V., Datsyuk V., et.al.: J. Appl. Polym. Sci., 2000, 76, 1228.

[3] Guyot A. and Tauer K.: Adv. Polym. Sci., 1994, 111, 43.

[4] Capek I.: Adv. Colloid Interface Sci., 2000, 88, 295.

[5] Busfield W. K., Jenkins I. D. and Heiland K.: Eur. Polym. J., $1994, \mathbf{3 0}, 1259$.

[6] Guillaume J. L., Pichot C. and Guillot J.: J. Polym. Sci., Part A: Polym. Chem., 1990, 28, 137.

[7] Fleychuk R.I., Hevus O.I. and Voronov S.A.: Russ. J. Org. Chem., 2003, 39 (12), 1799.
[8] Kohut A.M., Fleychuk R.I., Hevus O.I. and Voronov S.A.: 11 th Internarional Conference on Chemistry of Organic and Elementorganic Peroxides, 2003, 238.

[9] Siggia S. and Hanna J.G.: Quantitative Organic Analysis via Functional Groups. New York, J. Wiley \& Sons, 1979.

[10] Alfrey T., Bohrer J. J. and Mark H.: Copolymerization. New York, J. Wiley \& Sons, 1952.

\section{МАКРОІННЦАТОРИ НА ОСНОВІ НОВИХ ПЕРОКСИДНИХ ПОВЕРХНЕВО-АКТИВНИХ MOHOMEPIB}

Анотація. Досліджено поверхнево-активні властивості нових пероксидних малеїнатних мономерів. Вивчено закономірності їх кополімеризачії зі стиреном $i$ одержано пероксидвмісні полімери, які містять дитретинні алкільні пероксидні групи в бокових відгалуженнях основного макроланцюга - перспективні високотемпературні макроініціатори вільнорадикальних процесів.

Ключові слова: кополімеризачія, макромономери, мономери, пероксиди, поверхнево-активні речовини. 